\title{
Three-Dimensional Micro CT Derived Morphology of the Condylus mandibulae in Older Adults: Implications for Clinical Dentistry
}

\author{
Micro Tomografía Computarizada Tridimensional Derivada de la Morfología del Cóndilo \\ de la Mandíbula en Adultos Mayores: Implicaciones para la Odontología Clínica
}

\author{
Andrew S. Palombella ${ }^{1}$; Timothy D. Wilson ${ }^{2}$; Atson C. S. Fernandes ${ }^{2} \&$ Khadry A. Galil $^{2}$
}

\begin{abstract}
PALOMBELlA, A. S.; WILSON, T. D.; FERNANDES, A. C. S. \& GALIL, K. A. Three-dimensional micro ct derived morphology of the Condylus mandibulae in older adults: Implications for clinical dentistry. Int. J. Morphol., 37(3):787-791, 2019.

SUMMARY: Temporomandibular disorder (TMD) is a multi-etiologic disability, accompanied by a wide range of symptoms, requiring a variety of therapies, with TMJ reconstruction considered the most severe. TMJ surgery is associated with many morbidities and limitations, especially in the elderly. Previous studies have determined the shape and dimensions of the Condylus mandibulae in children and adults, but a range of measurements in the elderly population has yet to be created. This study aims to establish a range of measurements and the morphology of the Condylus mandibulae in an older population using micro CT. 14 cadaveric Condylus mandibulaes (8 male, 6 female; average age, 83 \pm 8.6 ) were scanned with microCT and measured using Amira 4.1.1 modeling software. The anteroposterior length (LAP), mediolateral width (WML) and height $(\mathrm{H})$ of each Condylus mandibulae was measured from 5 equidistant slices in the coronal, sagittal and axial planes. Additionally, each Condylus mandibulae was measured at its greatest anteroposterior length, mediolateral width and height using digital callipers on the cadaveric specimen. This study is the first to accurately describe the morphology of the Condylus mandibulae in an elderly population. The length and width measurements of digital calliper (10.51 $\pm 0.87 ; 18.33 \pm 2.35)$ and corresponding micro-CT $(11.46 \pm 1.60 ; 17.62 \pm 2.05)$ both showed high consistency and reliability. Our findings lay the foundation for the creation of an off-the-shelf Condylus mandibulae prosthesis or anatomically shaped Condylus mandibulae scaffold for elderly patients.
\end{abstract}

KEY WORDS: Condylus mandibulae; Morphology; MicroCT; Prosthesis; Elderly.

\section{INTRODUCTION}

Although the shape and dimension of the Condylus mandibulae (Head of mandible) have been described in children and adults (Meng et al., 2008; Cho et al., 2009; Karlo et al., 2010), it has yet to be analyzed in an elderly population. Additionally, Condylus mandibulae morphology has only been examined by measuring the largest Condylus mandibulae dimensions of both width (medial-lateral) and length (anterior-posterior) (Valladares Neto et al., 2010). With continued advancements in imaging technologies, it is important to determine the shape and dimension of the Condylus mandibulae with accuracy. This is of concern clinically, as a realistic and quantitative Condylus mandibulae model would have tremendous potential for temporomandibular joint (TMJ) reconstruction (Grayson et al., 2010).

Temporomandibular disorders (TMDs) are a collective term of clinical problems that involve the masticatory musculature, the TMJ and associated structures, or both (Wadhwa \& Kapila, 2008). Due to disabling TMDs, it has been estimated that almost 18 million workdays are lost each year for every 100 million fulltime working adults in the United States (Wadhwa \& Kapila) alone with roughly \$2 billion dollars are spent on treatment annually (Gatchel, 2010). There are a number of treatment options available, ranging from behavioural therapy (Gatchel) and oral splints (De Boever $e t$ al., 2008) to TMJ surgery (Dimitroulis, 2010) and prosthetics (Mercuri, 2000).

Although previous investigations have established measurements of the Condylus mandibulae in children and adults (Meng et al.; Cho et al.; Karlo et al.), the potential of altered shape and dimensions of the Condylus mandibulae in the elderly population remains unknown. Utilizing thin slice computed tomography (micro-CT) imaging to analyze the

\footnotetext{
${ }^{1}$ McMaster University, Faculty of Health Sciences, Education Program in Anatomy, 1280 Main Street West, HSC 1R7, Hamilton, ON, L8S 4K1, Canada. ${ }^{2}$ The University of Western Ontario, Schulich School of Medicine and Dentistry, Department of Anatomy and Cell Biology, Medical Sciences Building 490. London, ON, Canada N6A 5C1.
} 
Condylus mandibulae, the purpose of this study is to provide a realistic, descriptive and quantitative model with the potential to produce a superior assessment of the TMJ.

\section{MATERIAL AND METHOD}

Mandibular Sample. Seven right-sided and seven leftsided formalin-fixed Condylus mandibulaes were examined using micro-CT. Of the fourteen specimens, six were female and eight were male, while the age range was between 69 and 96 years.

All cadaveric subjects were obtained with permission from the Body Bequeathal Program at Western University, London ON, Canada, in accordance with the Anatomy Act of Ontario and Western's Committee for Cadaveric Use in Research.

Image Acquisition and Digital Measurements. Micro CT imaging was performed using a multi-slice micro-computed tomography scanner (GE Locus Ultra, GE Healthcare, and London, Ontario) at the Robarts Research Institute. Images were obtained at settings of $120 \mathrm{kV}, 20 \mathrm{~mA}, 16$ seconds exposure time and at a slice thickness of 154 micrometers $(\mu \mathrm{m})$. Following imaging, the micro CT raw data files were examined with a 3-dimensional visualization, measurement and modeling software (Amira 4.1., Visualization Sciences Group (VSG), Burlington, MA).

In the visualization software, an isosurface was created for each skull section containing the Condylus mandibulae. Isosurfaces are generated according to settings related to the attenuation coefficients of bone under the CT scanning parameters. Identical isosurface settings were used in the software across all skull sections. Creation of isosurfaces renders the image into a 3-dimensional virtual object, of the mandible, with high spatial resolution and retains all dimensional relationships such that further manipulations and measurements can be undertaken. Following isosurface creation, each virtual mandible was cropped of other accompanying anatomy to create specific of the areas of interest for ease of digital manipulation and faster computing time.

In order to acquire consistent measurements in the digital environment, a reference line, or plane in the 3D environment, was produced to ensure that all of the 3 dimensional skull sections were examined in the same orientation. The Frankfort Plane was used for the orientation of our bisected heads. The plane extends from the upper margin of the external auditory meatus posteriorly to the upper margin of the lower orbital rim anteriorly (Proffit et al., 2000).

Following the establishment of a reference plane, all Condylus mandibulae measures were made in relation to an orthogonal axes system determined by that plane. Measurements were then possible with each of the 14 Condylus mandibulaes in the coronal, sagittal and axial planes (Fig. 1). Parallel with each plane, five equidistant virtual cross-sections or 'slices' were created in the software. Therefore, fifteen unique slices were created for measurement within each Condylus mandibulae. Within each of the slices, multiple measures were determined using the calliper measuring tool within the software. For example, in each coronal slice, measurements of Condylus mandibulae height and medial-lateral length of the Condylus mandibulae were obtained (Figs. 1A-B). In each sagittal slice, the Condylus mandibulae height and anterior-posterior length of the Condylus mandibulae was measured (Figs. 1C-D). Finally, within each transverse slice, the medial-lateral length as well as the anterior-posterior length of the Condylus mandibulae was measured (Fig. 1E-F).

In addition to the measurements in Figure 1, each 3-dimensional Condylus mandibulae was also measured at its longest point (anterior to posterior) (Fig. 2A), widest point (medial to lateral) (Fig. 2C) and its greatest height (neck to top of Condylus mandibulae) (Fig. 2E).

Cadaveric Measurements. The digital measurements were reproduced on the specimens in the cadaveric laboratory. These measurements were then compared to identical measurements using the gold standard technique, a digital calliper device (Figs. 2B, D and F) on each specimen in order to assess the accuracy of micro CT and the reliability of the observers.

To ensure accuracy and reliability, all measurements were completed 4 times; twice by a primary observer and twice by a secondary observer using the same digital calliper (Mastercraft ${ }$, Canadian Tire).

Analysis. Analysis of the data were performed using IBM SPSS Statistics 19.0 (SPSS Inc., Chicago, IL) software program. Intraclass correlation coefficients (ICCs) were performed to assess the consistency between digital calliper and micro CT measurements, as well as intraobserver and inter-observer measurement reliability. Univariate analysis of variance (ANOVA) was performed to determine differences between digital calliper and micro CT measurements. 

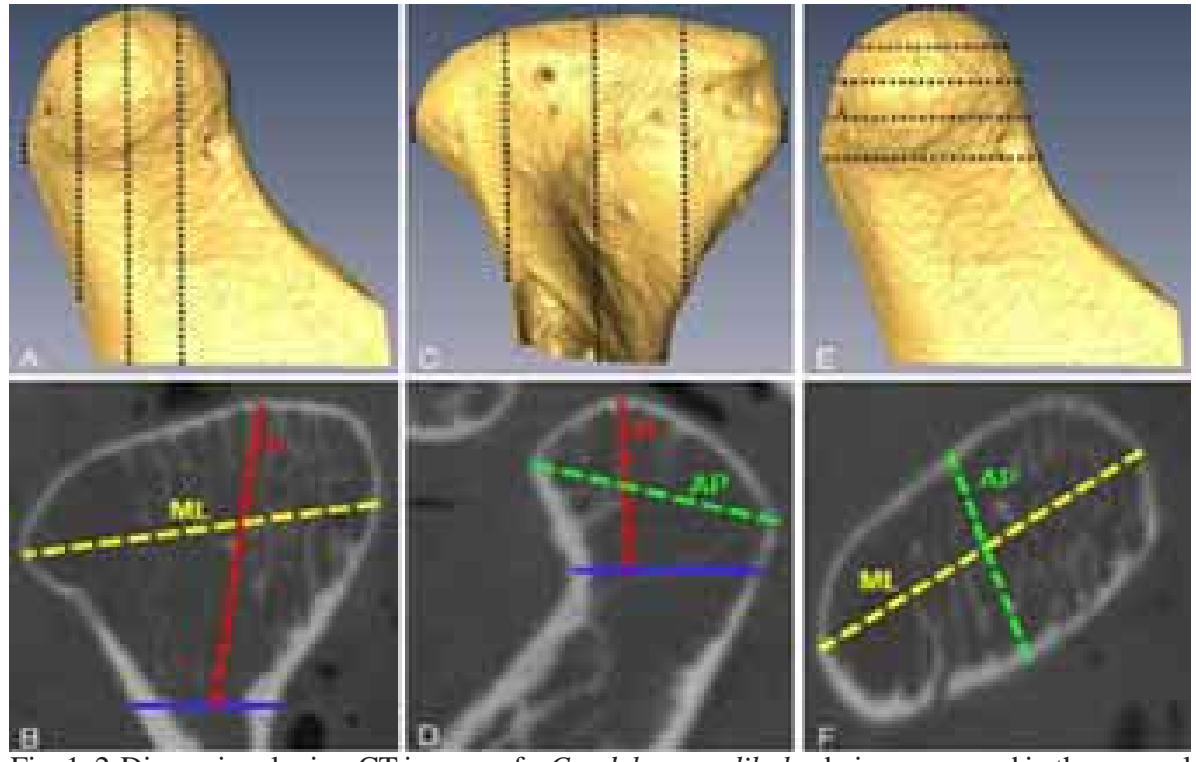

Fig. 1. 2-Dimensional microCT images of a Condylus mandibulae being measured in the coronal (A-B), sagittal (C-D) and axial (E-F) planes. Measurements are as follows: red H, Condylus mandibulae height; yellow ML, mediolateral Condylus mandibulae width; green AP, anteroposterior Condylus mandibulae length; blue, narrowest point of Collum mandibulae. Black lines represent equidistant slices in the coronal, sagittal and axial planes, respectively.
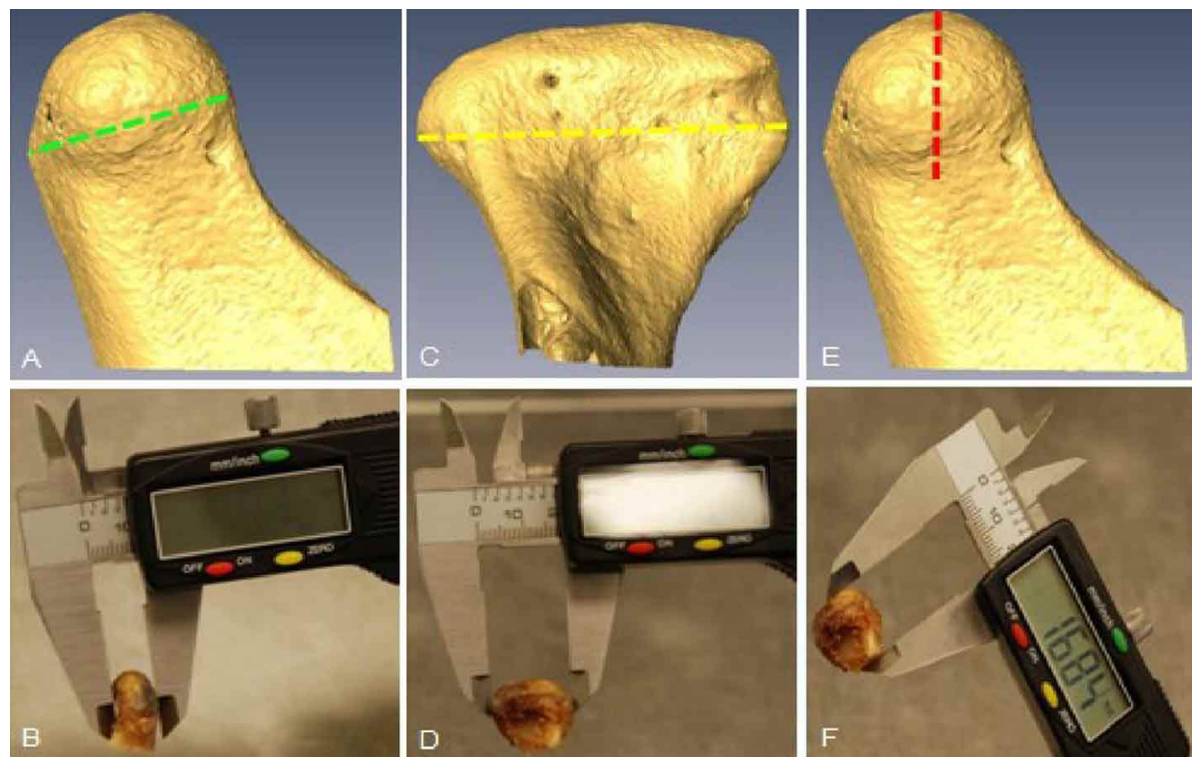

Fig. 2. MicroCT and corresponding cadaveric images of a Condylus mandibulae being measured at its longest point (A-B), widest point (C-D) and height (E-F). Green, anteroposterior Condylus mandibulae length; yellow, mediolateral Condylus mandibulae width; red, Condylus mandibulae height.

\section{RESULTS}

As intraclass correlation coefficients (ICC) was very high on digital calliper measurements: 0.97 (observers 1 and 2) and microCT measurements: 0.70 (observers 1 and 2), and fairly consistent comparing digital calliper and microCT measurements: 0.89 (observers 1 and 2), mean and standard deviation values were calculated for all digital calliper and microCT measurements, using the combined measurements of observer 1 and observer 2 (Tables I and II). Statistical analysis indicates that digital calliper and the corresponding 3-dimensional microCT measurements of the Condylus mandibulaes (Table I) were statistically similar for measures of width (medial-lateral) and length (anterior-posterior); however, measures of height (neck-top of condyle) were statistically not significant.

Mean and standard deviation values for 2 -dimensional microCT measurements for the 14 Condylus mandibulaes are presented in Table II. For images in the axial plane, slice 1 corresponds to the top of the Condylus mandibulae, while slice 5 corresponds to the neck of the condyle. For images in the coronal plane, slice 1 corresponds to the anterior portion of the Condylus mandibulae, while slice 5 corresponds to the posterior portion. Finally, for images in the sagittal plane, slice 1 corresponds to the lateral portion of the Condylus mandibulae, while slice 5 corresponds to the medial portion of the Condylus mandibulae. 
Table I. Descriptive statistics for digital calliper and corresponding 3-dimensional microCT measurements. The combined measurements of observers $1 \& 2$ were used to calculate the mean and standard deviation values $(\mathrm{mm})$.

\begin{tabular}{cccccc}
\hline \multicolumn{4}{c}{ LAP } & \multicolumn{2}{c}{ Digital Calliper vs. MicroCT } \\
WML & \multicolumn{2}{c}{$\mathrm{H}^{*}$} \\
\hline Calliper & $\mu$-CT & Calliper & $\mu$-CT & Calliper & $\mu$-CT \\
\hline 10.51 & 11.46 & 18.33 & 17.62 & 15.79 & 11.14 \\
{$[0.87]$} & {$[1.60]$} & {$[2.35]$} & {$[2.05]$} & {$[2.91]$} & {$[1.32]$} \\
\hline
\end{tabular}

Table II. Descriptive statistics for 2-dimensional microCT measurements. The combined measurements of observers $1 \& 2$ were used to calculate the mean and standard deviation values ( $\mathrm{mm}$ ).

\begin{tabular}{ccccccc}
\hline \multirow{5}{*}{ Slice } & $\mathrm{A}_{\mathrm{AP}}$ & $\mathrm{A}_{\mathrm{ML}}$ & $\mathrm{C}_{\mathrm{ML}}$ & $\mathrm{C}_{\mathrm{H}}$ & $\mathrm{S}_{\mathrm{AP}}$ & $\mathrm{S}_{\mathrm{H}}$ \\
\hline 1 & 1.55 & 2.04 & 3.91 & 3.06 & 1.46 & 1.22 \\
& {$[0.91]$} & {$[1.37]$} & {$[1.69]$} & {$[1.59]$} & {$[0.69]$} & {$[0.60]$} \\
2 & 9.66 & 14.62 & 14.36 & 10.33 & 9.27 & 10.07 \\
& {$[1.56]$} & {$[1.79]$} & {$[2.56]$} & {$[1.69]$} & {$[1.48]$} & {$[2.06]$} \\
3 & 12.07 & 17.04 & 15.98 & 11.77 & 10.39 & 11.01 \\
& {$[1.82]$} & {$[2.34]$} & {$[2.09]$} & {$[3.02]$} & {$[0.78]$} & {$[1.60]$} \\
4 & 11.56 & 15.90 & 13.23 & 10.68 & 8.79 & 10.61 \\
& {$[1.96]$} & {$[3.60]$} & {$[1.72]$} & {$[2.60]$} & {$[1.52]$} & {$[2.21]$} \\
5 & 10.70 & 13.49 & 2.43 & 2.41 & 1.19 & 1.20 \\
& {$[1.69]$} & {$[3.51]$} & {$[1.20]$} & {$[1.43]$} & {$[0.81]$} & {$[1.16]$} \\
\hline
\end{tabular}

of width, length and height in five equidistant slices in the coronal, sagittal and axial planes (Table II). These additional indices produce a much more accurate representation of the Condylus mandibulae in the older population. The results of this study will be especially useful to oral and maxillofacial surgeons and tissue engineers, as our findings lay the foundation for the creation of an off-the-shelf Condylus mandibulae prosthesis or anatomically shaped scaffold in an elderly population. An accurate and realistic off-the-shelf Condylus mandibulae prosthesis would not only improve TMJ function, reduce disability and prevent further morbidity in an individual suffering from TMD (Mercuri), but it would also reduce treatment cost as there is no need to create a custom Condylus mandibulae prosthesis for every patient.

Since both inter-observer and intra-observer correlation coefficients were high (digital calliper: observer $1-0.93$, observer 2-0.88, observers 1\&2 - 0.97; MicroCT: observer 1 - 0.96, observer $2-0.95$, observers $1 \& 2-0.70$; digital calliper x MicroCT: observer $1-0.81$, observer $2-0.68$, observers $1 \& 2$ - 0.89), we were able to combine data creating mean values based on four sets of measurements (Tables I and II). Although we did have one intra-observer value below 0.7 (0.68), it was still within the range of 0.3 and 0.7 which is considered a moderately strong relationship (Ratner, 2015). Since the remaining inter-observer and intra-observer correlation coefficients are within the range of 0.7 and 1 , we decided to combine all of our data.
It is well established that $\mathrm{CT}$ imaging provides an excellent representation of TMJ bone tissue, erosion and osteophytes, and that many studies have shown CT to be very accurate for linear measurements (Valladares Neto et al.). In the current study, microCT measurements of greatest width (mediolateral), length (anteroposterior) and height of the Condylus mandibulaes were compared to identical digital calliper measurements of cadaveric specimens (Table I). This was done not only to test the reliability of our observers, but also to test the accuracy of microCT as a measuring tool in this confined space. In line with previous studies, our microCT measurements of greatest width (mediolateral) and length (anteroposterior) were statistically similar to cadaveric measurements; our measurements of Condylus mandibulae height, however, were statistically different.

During Condylus mandibulae height determination, a limitation was encountered. Here the discrepancy in height measurements between microCT and digital calliper can be explained by the observers' inability to accurately create a starting point by demarcating a single reference line on the Collum mandibulae (neck of mandible) for both modalities of measurement. Because there are no known reference lines like the Frankfort plane, a Collum mandibulae reference point was selected prior to our microCT measurements, and again, prior to our digital calliper measurements which most likely accounts for the discrepancies in height measures.

\section{CONCLUSIONS}

The present study is the first to accurately analyze the morphology of the Condylus mandibulae in an elderly population using microCT. Previous studies in children and adults measured the Condylus mandibulae at its greatest width (mediolateral), length (anteroposterior) and height. In addition to making similar measurements, the current study also addressed the width, length, and height of each Condylus mandibulae across five equidistant slices in each orthogonal plane. This approach enabled accurate representation of the Condylus mandibulae, while our results form the foundation for an off-the-shelf Condylus mandibulae prosthesis or anatomically shaped scaffold in an elderly population.

We believe that to accurately determine the morphology of the Condylus mandibulae in elderly patients to create an off-the-shelf Condylus mandibulae prosthesis or scaffold, the shape and dimensions of the Condylus mandibulae must be measured in a large, mixed and healthy study sample. It is important that all specimens measured belong to asymptomatic subjects so we can confidently describe normal mandibular morphology. 
PALOMBELla, A. S.; WILSON, T. D.; FERNANDES, A. C. S. \& GALIL, K. A. Microtomografía computarizada tridimensional derivada de la morfología del cóndilo de la mandíbula en adultos mayores: Implicaciones para la odontología clínica. Int.J. Morphol., 37(3): 787-791, 2019.

RESUMEN: El trastorno temporomandibular (TTM) es una discapacidad multi-etiológica, acompañada por una amplia gama de síntomas, que requieren una variedad de terapias, entre las cuales la reconstrucción de la articulación temporomandibular (ATM) es considerada una de las terapias más graves. La cirugía de la ATM se asocia con muchas morbilidades y limitaciones, especialmente en adultos mayores. Estudios previos han determinado la forma y las dimensiones del cóndilo de la mandíbula en niños y adultos, no obstante aún no se han identificado estas mediciones en una población de adultos mayores. Este estudio tiene como objetivo establecer un rango de mediciones y la morfología del cóndilo de la mandíbula en una población de adultos mayores mediante microtomografía computarizada (microCT). Se escanearon, con microCT, 14 mandíbulas cadavéricas ( 8 hombres, 6 mujeres; edad promedio: $83 \pm 8,6$ años), y se realizaron mediciones utilizando el software de modelado Amira 4.1.1. De cada cóndilo de la mandíbula se midió: longitud anteroposterior (LAP), ancho mediolateral (AML) y altura (A), a partir de 5 cortes equidistantes en los planos coronal, sagital y axial. Además, también se utilizaron calibradores digitales para realizar estas mismas mediciones. Este estudio es el primero en describir con precisión la morfología del cóndilo de la mandíbula en una población de adultos mayores. Las medidas de longitud y anchura del calibrador digital $(10,51 \pm 0,87 ; 18,33 \pm 2,35)$ y el micro-CT correspondiente $(11,46 \pm 1,60 ; 17,62 \pm 2,05)$ mostraron una alta consistencia y confiabilidad. Nuestros hallazgos sientan las bases para la creación de una prótesis de cóndilo de la mandíbula o un andamio condilar de forma anatómica para pacientes de edad avanzada.

PALABRAS CLAVE: Cóndilo de la mandíbula; Morfología; microCT; Prótesis; Adultos mayores.

\section{REFERENCES}

Cho, B. H.; Ahn, Y. W. \& Jung, Y. H. Comparison of mandibular morphology between patients with temporomandibular joint osteoarthritis and asymptomatic normal subjects. Quintessence Int., 40(8):e49-54, 2009.

De Boever, J. A.; Nilner, M.; Orthlieb, J. D.; Steenks, M. H. \& Educational Committee of the European Academy of Craniomandibular Disorders. Recommendations by the EACD for examination, diagnosis, and management of patients with temporomandibular disorders and orofacial pain by the general dental practitioner. J. Orofacial Pain, 22(3):268-78, 2008.

Dimitroulis, G. TMJ Major Surgery. In: Manfredini, D. (Ed.). Current Concepts on Temporomandibular Disorders. Berlin, Quintessence Publishing Co. Ltd., 2010. pp.403-15.

Gatchel, R. J. Behavioural Treatment Approaches to Temporomandibular Joint and Muscle Disorders. In: Manfredini, D. (Ed.). Current Concepts on Temporomandibular Disorders. Berlin, Quintessence Publishing Co. Ltd., 2010. pp.319-26.

Grayson, W. L.; Fröhlich, M.; Yeager, K.; Bhumiratana, S.; Chan, M. E.; Cannizzaro, C.; Wan, L. Q.; Liu, X. S.; Guo, X. E. \& Vunjak-Novakovic,
G. Engineering anatomically shaped human bone grafts. Proc. Natl. Acad. Sci. U. S. A., 107(8):3299-304, 2010.

Karlo, C. A.; Stolzmann, P.; Habernig, S.; Müller, L.; Saurenmann, T. \& Kellenberger, C. J. Size, shape and age-related changes of the Condylus mandibulae during childhood. Eur. Radiol., 20(10):2512-7, 2010.

Meng, F.; Liu, Y.; Hu, K.; Zhao, Y.; Kong, L. \& Zhou, S. A comparative study of the skeletal morphology of the temporo-mandibular joint of children and adults. J. Postgrad. Med., 54(3):191-4, 2008.

Mercuri, L. G. The use of alloplastic prostheses for temporomandibular joint reconstruction. J. Oral Maxillofac. Surg., 58(1):70-5, 2000.

Proffit, W. R.; Fields, W. R. Jr.; Ackerman, J. L.; Bailey, L. J. \& Tulloch, J. F. C. Contemporary Orthodontics. 3rd ed. St. Louis (Missouri), Mosby Inc., 2000.

Ratner, B. The Correlation Coefficient: Definition. North Woodmere, DM STAT-1 CONSULTING, 2015. Available from: http:// www.dmstat 1.com/res/TheCorrelationCoefficientDefined.html

Valladares Neto, J.; Estrela, C.; Bueno, M. R.; Aguirre Guedes, O.; Porto, O. C. L. \& Pécora, J. D. Condylus mandibulae dimensional changes in subjects from 3 to 20 years of age using Cone-Beam Computed Tomography: a preliminary study. Dent. Press J. Orthod., 15(5):172$81,2010$.

Wadhwa, S. \& Kapila, S. TMJ disorders: future innovations in diagnostics and therapeutics. J. Dent. Educ., 72(8):930-47, 2008.

\section{Corresponding author:}

Atson Fernandes. DDS, MSc, Ph.D

The University of Western Ontario

Schulich School of Medicine and Dentistry

Department of Anatomy and Cell Biology

Medical Sciences Building 490

London, Ontario

CANADA

Email: adesou9@uwo.ca; atsonfernandes@yahoo.com.br

Received: 18-09-2018

Accepted: 12-03-2019 